\title{
How Long-Term Chemical Fertilization of Sloping Cropland Enhances Yield and Fertility without Compromising Coil Structure
}

\author{
Mingxiang Xu' ${ }^{1 *}$ Qiang $\mathrm{Li}^{2}$, Matthew Bowker ${ }^{3}$ \\ ${ }^{1}$ State Key Laboratory of Soil Erosion and Dry Land Farming, Northwest A \& F University, \\ 26 Xinong RD, Yangling, 712100, Shaanxi, China \\ ${ }^{2}$ College of Life Science, Yulin University, 4 Chongwen RD, Yulin, Shaanxi 719000, China \\ ${ }^{3}$ School of Forestry, Northern Arizona University, Flagstaff, 86011, AZ, USA
}

Received: 6 January 2017

Accepted: 16 February 2017

\begin{abstract}
We studied the effects of the long-term (17 years) application of different chemical fertilizer regimes on soil $\mathrm{N}$ and its inorganic fractions in relation to the soil physical properties in a sloping cropland in the hilly Loess Plateau. Seven treatments comprised of two factors were arranged within a randomized complete block design. As expected, crop yield increased 2-4-fold, but soil structure did not degrade. Under long-term fertilization, the portion of the small aggregates $(<2 \mathrm{~mm})$ and sand content were significantly decreased while the large aggregates $(>2 \mathrm{~mm})$ and the silt content increased by $276 \%$ and $7.4 \%$, respectively, as compared with those in areas without fertilization. Moreover, the various continuous chemical fertilization treatments increased SOC content by $12.9 \%$ and total $\mathrm{N}$ by $12.4 \%$, on average, compared with unfertilized plots. The SOC, total $\mathrm{N}$, and shoot $\mathrm{C}$, shoot $\mathrm{N}$ had close relationships with the large aggregates $(>2 \mathrm{~mm})$ and the clay content. The results suggest that, in this setting, the long-term addition of both $\mathrm{N}$ and $\mathrm{P}$ may sustain soil quality of an infertile sloping cropland in this region, compared to agriculture without fertilizer or applications of $\mathrm{N}$ alone.
\end{abstract}

Keywords: soil nitrogen fractions, physical properties, soil organic carbon, soil microbial biomass carbon, optimal fertilizer treatment

\section{Introduction}

In recent decades, chemical fertilizer has been applied extensively to meet the world's increasing demand for food. This will be especially true in the mountainous and other marginal regions of the world where higher crop production will be demanded to meet the increasing

*e-mail: xumx@nwsuaf.edu.cn food needs of a large population vulnerable to food insecurity. To eradicate hunger and achieve the 2030 agenda for sustainable development [1], it is therefore important to fully understand the positive and negative long-term impacts of inorganic fertilizer application on sloping cropland, since we can expect the practice to be more prevalent in the future as populations continue to grow. Past research has reported that long-term chemical fertilizer applications increased water stable aggregation, porosity, infiltration capacity, and hydraulic conductivity, 
and decreased bulk density, and has attributed these changes to the increased crop yields and organic matter returns compared with no fertilizer application [2-4]. However, long-term chemical fertilizer application could change the ion balance in soil solutions, greatly influencing dispersion/flocculation of soil clay particles and thus soil aggregation [5]. Soil structure could degrade, which would be indicated by a loss of aggregate stability and increase in bulk density[6]. Rational fertilizer application on sloping cropland could improve soil structure and erodibility, and change erosion-induced soil particle (clay, silt, and sand) separation, causing an indirect impact on soil texture [7-9]. The effects of chemical fertilizer applications on soil physical properties are complex and depend on the cropping system, environmental conditions, and fertilization regime $[8,10]$. Thus far, knowledge of the effects of long-term chemical fertilization on soil physical properties in mountainous regions are limited and complicated by erosion stress and a legacy of deeply eroded, infertile soil.

There are a number of possible benefits of $\mathrm{N}$ fertilization that could be realized. Soil nitrogen $(\mathrm{N})$ concentration and its availability are generally associated with soil organic carbon (SOC), because $\mathrm{N}$ increases production and therefore SOC, and SOC can serve as an $\mathrm{N}$ reservoir [11-12]). Adequate $\mathrm{N}$ application might not only enhance production and $\mathrm{N}$ stocks, but as a result also increase soil microbial abundance or functionality, potentially feeding back to facilitate suitable conditions for root growth of plants. On the other hand, the previously mentioned degradation of soil structure and subsequent decline of crop yield could occur, especially in intensively cultivated slope lands [13-14]. Therefore, a panel of distinguished cropland scientists and economists are considering the search for an efficient $\mathrm{N}$ utilization strategy, balancing these potential benefits and risks as a top priority [15-16].

Long-term field experiments provide direct observations of changes in SOC storage and $\mathrm{N}$ balance, and are critical for the predictions of future soil productivity and soil-environment interactions [17-18]. Soil C:N ratio is one of the reliable indicators that responds sensitively to long-term $\mathrm{N}$ fertilization studies [19-20]. The issues related to SOC fractions and mineralization rates and their relationships with certain factors, such as soil structure, are well documented in various soils and cropping systems [21-23]. However, information on soil $\mathrm{N}$ and its inorganic fractions in relation to physical properties are minimal, especially under the long-term application of chemical fertilizer [24-25]. Such information plays a crucial role in maintaining efficient $\mathrm{N}$ utilization and sustainable agriculture.

The hilly Loess Plateau (a deep, loamy, eolian deposit) is located in northwestern China with its hilly and gully mountain landscape. It has a typical continental climate, which is characterized by seasonal precipitation, a dry climate, intensive evaporation, and frequent natural disasters such as floods and landslides. Numerous studies have demonstrated that organic fertilization or a combination of organic and inorganic fertilization are the most effective ways to increase crop productivity and improve soil quality in the region [26-27]. However, with the implementation and strengthening of the two major land use policies (the 'grain for green' and 'closing mountain and prohibiting pasturage' projects) [28], local organic fertilizer has gradually become scarce as a result of decreasing livestock numbers. The lessened availability of organic fertilizer has made chemical fertilizers the sole option for local farmers at present and in the near future [29]. Therefore, it is particularly important to investigate the evolution of soil quality with successive chemical fertilization and to choose appropriate scientific measurements to gauge the local soil quality for a sustainable agricultural system.

This study has attempted to investigate the changes in $\mathrm{SOM}$, soil $\mathrm{N}$ concentration and its fractions, as well as soil physical properties in soy (Glycine max Linn. Merr.)broomcorn (Panicum miliaceum Linn.)-millet (Setaria italica L. Beauv.) cropping systems on slopes amended with different chemical fertilization regimes for 17 years. We hypothesize that long-term chemical fertilizer application could lead to degradation of soil physical properties (such as degree and stability of aggregation) on the sloping cropland under an environment that favors erosion. We also aimed to evaluate the long-term effects of inorganic fertilizers on soil physical properties and total $\mathrm{N}$ and its inorganic $\mathrm{N}$ fractions, as well as their relationships with the physical properties in the hilly Loess Plateau region. The results may provide scientific reference for sustainable management of sloping cropland in the mountainous regions of the world.

\section{Material and Methods}

\section{Description of Long-Term Field Experiment}

The long-term chemical fertilization experiment was established in 1992 on cropland with a slope gradient of 19 degrees. It employed a soy-broomcorn-millet cropping system in the Ansai Field Experiment Station of the Chinese Academy of Sciences in northwestern China $\left(36^{\circ} 51^{\prime} 22^{\prime \prime} \mathrm{N}\right.$, $109^{\circ} 18^{\prime} 52^{\prime \prime E}$ ). The study region has a typical semiarid climate, with an annual mean temperature of $8.8^{\circ} \mathrm{C}$ and annual precipitation of $505.3 \mathrm{~mm}$. The loessial soil, which is the predominant type in the area, evolved directly from yellow-colored wind-deposited material, with uniform soil texture by depth. These soils are classified as Entisols in the United States Department of Agriculture (USDA) classification system [30]. In general, soils in croplands of the region are characterized as silt loams with the following properties: clay content $21.6 \pm 3.7 \%$, dry bulk density of the cultivated layer $1.19 \pm 0.06 \mathrm{~g} \mathrm{~cm}^{-3}$, CEC $4.76 \pm 0.26 \mathrm{cmol} \mathrm{kg}^{-1}, \mathrm{CaCO}_{3} 105 \pm 15 \mathrm{~g} \mathrm{~kg}^{-1}, \mathrm{pH} 8.75 \pm 0.16$, and organic matter $6.15 \pm 2.4 \mathrm{~g} \mathrm{~kg}^{-1}$ [31].

Seven treatments (N0P0, N1P0, N2P0, N1P1, N1P2, $\mathrm{N} 2 \mathrm{P} 1$, and $\mathrm{N} 2 \mathrm{P} 2$ ), comprised of two factors ( $\mathrm{N}$ addition rate, $P$ addition rate) were each applied at three levels, with two replicates, and were arranged within a randomized 
Table 1. Fertilizer inputs in $\mathrm{kg} \mathrm{ha}^{-1} \mathrm{yr}^{-1}$ of the treatments.

\begin{tabular}{|c|c|c|c|c|c|c|c|}
\hline $\begin{array}{c}\text { Treatment } \\
\text { Fertilizers }\end{array}$ & N0P0 & N1P0 & N2P0 & N1P1 & N1P2 & N2P1 & N2P2 \\
\hline $\begin{array}{c}\text { N fertilizer } \\
\text { Pure N/ } \text { kg ha }^{-1} \mathrm{yr}^{-1}\end{array}$ & 0 & 55.2 & 110.4 & 55.2 & 55.2 & 110.4 & 110.4 \\
\hline $\begin{array}{c}\text { P fertilizer } \\
\mathrm{P}_{2} \mathrm{O}_{5} / \mathrm{kg} \mathrm{ha}^{-1} \mathrm{yr}^{-1}\end{array}$ & 0 & 0 & 0 & 45 & 90 & 45 & 90 \\
\hline
\end{tabular}

complete block design. Each plot was $3 \times 8 \mathrm{~m}$. The amount of fertilizer added in the respective plots is described in Table 1. Millet (Jinfen 7) was sown at a density of 16 plants $\mathrm{m}^{-2}$ in April. The soil was hand-plowed with hoes before sowing each year. $\mathrm{N}$ was applied as urea (46\% $\mathrm{N}$ content) and $\mathrm{P}$ was applied as triple superphosphate (44\% $\mathrm{P}_{2} \mathrm{O}_{5}$ content). The fertilization was split into two applications, $20 \%$ of the total amount was applied as a basal fertilizer and the remaining fertilizer was top-dressed during the jointing stage. The above-ground biomass was removed during harvest and little residue remained.

\section{Plant and Soil Sampling and Analysis}

At harvest, two or three rows of millet in each plot were chosen to measure the yield, biomass, and other plant response variables. Plant shoots were classified into leaves, culms, chaffs, and grains. Fresh samples were sun-dried until a constant weight was reached and the aboveground part was chopped, finely ground with a Wiley Mini Mill (Thomas Scientific, USA), and passed through a $0.25 \mathrm{~mm}$ sieve. These data were used to calculate nitrogen use efficiency and other indices. Total $\mathrm{N}$ and total $\mathrm{C}$ concentrations in the plant tissue samples were determined using the $\mathrm{H}_{2} \mathrm{SO}_{4}-\mathrm{H}_{2} \mathrm{O}_{2}$ digestion method [32].

We divided each plot into two subplots from which we sampled soils; these duplicate measurements were then averaged for the whole plot prior to inferential statistical analysis. This practice allowed us to better represent each plot and reduce measurement error at the plot-level. Intact soil was sampled from each subplot for aggregate stability determination. Composite soil samples from the surface soil $(0-15 \mathrm{~cm})$ of each subplot were collected using a stainless steel corer with $5 \mathrm{~cm}$ diameter after the millet harvest. Subsequently, the soil samples were thoroughly mixed and then the visible pieces of crop residue and roots were removed by hand. Samples for biological analysis were placed in sealed plastic bags covered with ice packs for transport to the laboratory where they were refrigerated no more than three weeks until processing. Samples for chemical analysis were air-dried in the laboratory. Parts of the samples were stored in dark conditions, and the representative sub-samples were immediately extracted using $2 \mathrm{M} \mathrm{KCl}$ solution (soil solution ratio: 1:5) and through shaking for $1 \mathrm{~h}$ on a rotary shaker $\left(180 \mathrm{rev} \mathrm{min}^{-1}\right)$, followed by filtration. The extracts were directly analyzed for the content of $\mathrm{NO}_{3}^{-}-\mathrm{N}$ and $\mathrm{NH}_{4}^{+}-\mathrm{N}$ contents by using an automated continuous flow analyzer (Alliance/ PROXIMA, France). The remaining samples were ground to pass through a $1-\mathrm{mm}$ sieve prior to the determinations of available N. Further, grinding was performed to allow passage through a $0.25 \mathrm{~mm}$ sieve prior to determining soil organic carbon (SOC) and total N. Soil bulk density was also sampled by collecting undisturbed soil cores (stainless steel cylinders with a diameter and a height of $5 \mathrm{~cm}$ each) in the middle of the $0-15 \mathrm{~cm}$ depth increment. Soil aggregation was determined by an improved Yoder method (Kemper and Rosenau, 1986 [31]). Five aggregate size classes $(>5,5-2,2-1,1-0.5,0.5-0.25 \mathrm{~mm})$ were obtained with sieves of $5,2,1,0.5$, and $0.25 \mathrm{~mm}$. SOC was determined using the modified Walkley-Black method [33]. Total $\mathrm{N}$ and available $\mathrm{N}$ were determined using the method of Kjeldahl and alkaline potassium permanganate distillation, respectively [32]. Microbial biomass C (MBC) was determined on $50 \mathrm{~g}$ samples by chloroform fumigation and direct extraction with $0.5 \mathrm{M} \mathrm{K}_{2} \mathrm{SO}_{4}$ using duplicate 2-mm sieved field-moist soil samples. MBC was calculated using the correction factors 2.64 [34]. The soil particle group (USDA texture classification) was determined using the Malvern Size 2000 method (Malvern Company, Britain). The samples were pretreated with $6 \%$ $\mathrm{H}_{2} \mathrm{O}_{2}$ to remove organic matter and added 10\% HCL for removing carbonates and oxides, and then were soaked in distilled water for $72 \mathrm{~h}$. After removing the distilled water, the samples were chemically dispersed with $0.4 \%$ Calgon and mechanically dispersed in an ultrasonic bath for 30 seconds before particle group measurement.

\section{Calculation Methods}

The internal $\mathrm{N}$ use efficiency (IE) represents the acquired yield per $\mathrm{N}$ uptake [35], which can be calculated as follows:

$$
\mathrm{IE}=\mathrm{Y} / \mathrm{U}
$$

... where $\mathrm{Y}$ is the grain yield $\left(\mathrm{kg} \mathrm{ha}^{-1}\right)$ and $\mathrm{U}$ is the $\mathrm{N}$ uptake by the aboveground shoot $\left(\mathrm{N}, \mathrm{kg} \mathrm{ha}^{-1}\right)$.

$\mathrm{N}$ use efficiencies [24] are calculated by:

$\mathrm{N}$ agronomic efficiency ( $\mathrm{NAE}, \mathrm{kg} \mathrm{kg}^{-1}$ ) = (grain yield at $\mathrm{Nx}-$ grain yield at $\mathrm{N} 0$ )/applied $\mathrm{N}$ at $\mathrm{N}$.

$\mathrm{N}$ apparent recovery efficiency $(\mathrm{NRE}, \%)=$ ( $\mathrm{N}$ uptake at $\mathrm{Nx}-\mathrm{N}$ uptake at $\mathrm{N} 0$ )/applied $\mathrm{N}$ at $\mathrm{N}$. 
The sustainable yield index (SYI) is an indicator for evaluating cropland sustainability, and it can be defined as follows:

$$
\mathrm{SYI}=\frac{\overline{\mathrm{Y}}-\sigma}{\mathrm{Y}_{\max }}
$$

... where $\bar{Y}$ is the estimated average yield of a practice over time, $\sigma$ is its estimated standard deviation, and $\mathrm{Y}_{\max }$ is the observed maximum yield in the experiment.

\section{Data Analysis}

Linear regression was used to analyze the rate of aggradation of soil carbon and nitrogen through time. The trend lines of SOC and soil TN during 17 years (Figs 1 and 2) were fit to three-year means. This rolling average

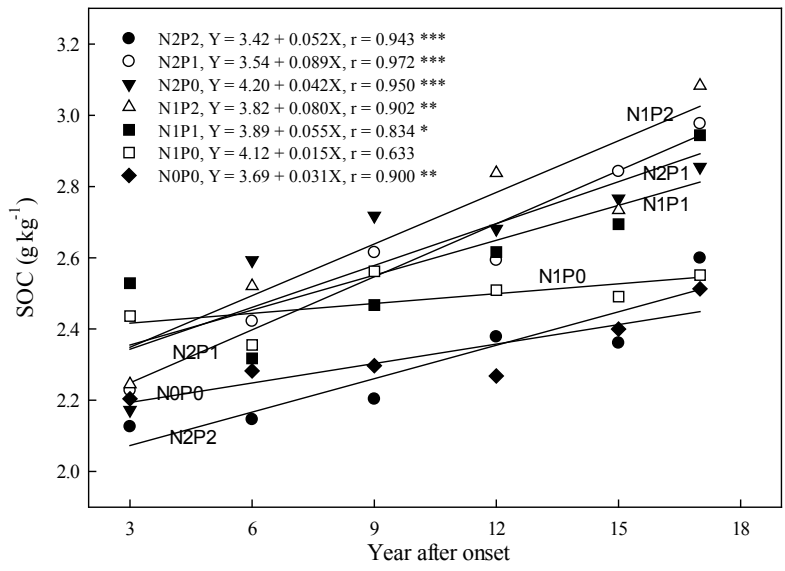

Fig. 1. Changes in SOC content in the different treatments over a period of 17 years.

$*$, **, and *** denote significance at $P<0.05, P<0.01$, and $P<0.001$, respectively.

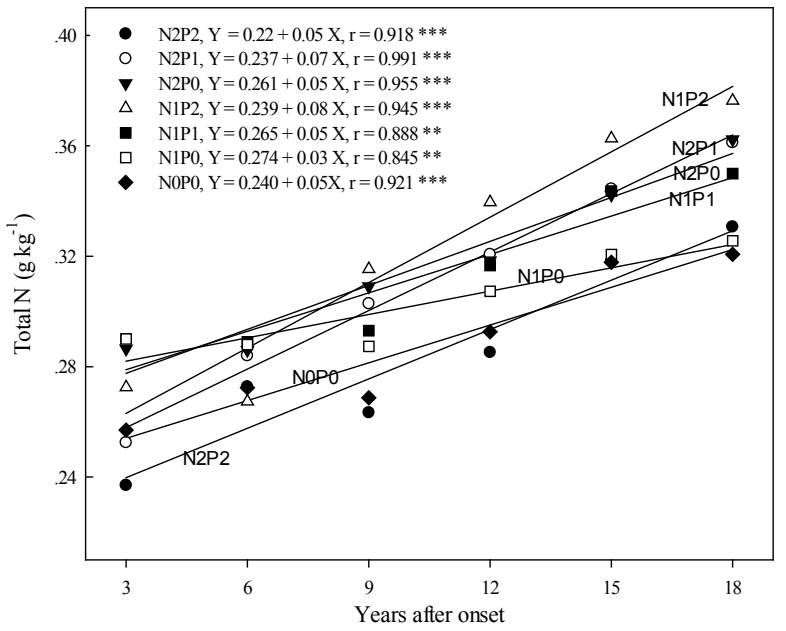

Fig. 2. Changes in soil total $\mathrm{N}$ content in the different treatments over a period of 17 years.

** and *** denote significance at $P<0.01$ and $P<0.001$, respectively. approach was intended to smooth year-to-year variability attributed to climate variation, and instead allows us to focus on differences in fertilizer regimes.

One-way analysis of variance (ANOVA) was performed to investigate the changes in soil $\mathrm{N}$ fractions and soil physical properties produced by different chemical fertilizer treatments after 17 years, and the least significant difference test (LSD) was applied post-hoc to determine which factor levels differed from one another. These analyses were based on 2009 data (Table 2). The Pearson correlation coefficient was used to analyze the correlation among soil chemical and physical properties. Due to limited replication in the long-term experiment, we use the values of those data in 2005, 2007, and 2009 in each plot as replicates in correlation analysis to account for correlation in both space and time. We tested the data for normal distributions and, when required, we used logarithmic transformations. All statistics were performed in SPSS13.0 (SPSS Inc, Chicago, USA).

\section{Results and Discussion}

\section{Changes in SOC and Millet Yield under Different Treatments}

The continuous chemical fertilizer application (except for N1P0 treatment) significantly increased the SOC concentration from $2.1 \mathrm{~g} \mathrm{~kg}^{-1}$ to $2.4 \mathrm{~g} \mathrm{~kg}^{-1}$ at the beginning of the experiment to $2.5 \mathrm{~g} \mathrm{~kg}^{-1}$ to $3.1 \mathrm{~g} \mathrm{~kg}^{-1}$ in 2009 (Fig. 1). In all treatments, most of the SOC was crop root biomass because the aboveground biomass was removed during harvest and little residue remained. Compared with NOP0, the fertilized treatments attained higher SOC contents, with an average increment of $12.9 \%$ among different fertilizer treatments after 17 years. The increments were similar to results from central China, in which $\mathrm{N}$ and $\mathrm{P}$ treatments lead to $10 \%$ annual incremental increases of SOC compared with NOP0 [36]. Similar results were observed in a sandy loam soil south of Jutland, Denmark, in which NPK treatment increased SOC by $11 \%$ compared with unfertilized soil after 90 years [37]. However, the increases we saw were comparatively higher than other research results from the Loess Plateau, where the SOC increased $2.0 \%$ and $3.1 \%-13.3 \%$ in N and NP treatments compared with N0P0 [38]. The SOC gains due to chemical fertilization in sloped crops were much smaller compared to other settings in the study region, such as highly productive soil amended with organic fertilizer and long-term terrace amended with chemical fertilizer [39]. The differences of the former might be due to a higher fertilizer input amount, but the differences of the latter could be attributed to soil erosion amelioration by terraces, and therefore more retention of SOC. Therefore, the conversion of slope land to terrace in the hilly Loess Plateau should be encouraged for a more efficient agriculture, and more efficient use of either organic or chemical fertilizers. 
Table 2. Soil physical properties of long-term chemical fertilized slope cropland after 17 years (data in 2009).

\begin{tabular}{|c|c|c|c|c|c|c|c|}
\hline \multirow{2}{*}{ Parameters } & \multicolumn{7}{|c|}{ Treatments } \\
\hline & NOP0 & N1P0 & $\mathrm{N} 2 \mathrm{P} 0$ & N1P1 & $\mathrm{N} 1 \mathrm{P} 2$ & $\mathrm{~N} 2 \mathrm{P} 1$ & $\mathrm{~N} 2 \mathrm{P} 2$ \\
\hline Bulk density $\left(\mathrm{g} \mathrm{cm}^{-3}\right)$ & $1.19 \mathrm{a}$ & $1.22 \mathrm{a}$ & $1.21 \mathrm{a}$ & $1.21 \mathrm{a}$ & $1.20 \mathrm{a}$ & $1.23 \mathrm{a}$ & $1.21 \mathrm{a}$ \\
\hline Porosity $\left(\%, \mathrm{v} \mathrm{v}^{-1}\right)$ & $54.93 \mathrm{a}$ & $54.03 \mathrm{a}$ & $54.40 \mathrm{a}$ & $54.36 \mathrm{a}$ & $54.36 \mathrm{a}$ & $53.64 \mathrm{a}$ & $53.64 \mathrm{a}$ \\
\hline \multicolumn{8}{|c|}{ Aggregate size distribution (\%) } \\
\hline$>5 \mathrm{~mm}$ & $4.09 \mathrm{e}$ & $5.43 \mathrm{e}$ & $16.49 \mathrm{~cd}$ & $30.32 \mathrm{~b}$ & $49.06 \mathrm{a}$ & $47.54 \mathrm{a}$ & $8.09 \mathrm{de}$ \\
\hline $5-2 \mathrm{~mm}$ & $8.16 \mathrm{~b}$ & $14.13 \mathrm{a}$ & $5.49 \mathrm{~b}$ & $9.02 \mathrm{ab}$ & $9.43 \mathrm{ab}$ & $7.73 \mathrm{~b}$ & $8.67 \mathrm{~b}$ \\
\hline $2-1 \mathrm{~mm}$ & $12.24 \mathrm{ab}$ & $8.70 \mathrm{abc}$ & $6.04 \mathrm{c}$ & $12.30 \mathrm{ab}$ & $\begin{array}{l}9.75 \\
a b c\end{array}$ & $7.26 \mathrm{bc}$ & $13.87 \mathrm{a}$ \\
\hline $1-0.5 \mathrm{~mm}$ & $26.53 \mathrm{bc}$ & $22.83 \mathrm{~cd}$ & $60.44 \mathrm{a}$ & $\begin{array}{c}25.00 \\
\text { bcd }\end{array}$ & $14.15 \mathrm{e}$ & $18.03 \mathrm{de}$ & $30.64 \mathrm{~b}$ \\
\hline $0.5-0.25 \mathrm{~mm}$ & $48.98 \mathrm{a}$ & $48.91 \mathrm{a}$ & $11.54 \mathrm{~d}$ & $23.36 \mathrm{c}$ & $\begin{array}{c}17.61 \\
\mathrm{~cd}\end{array}$ & $19.44 \mathrm{~cd}$ & $38.73 \mathrm{~b}$ \\
\hline Amount of aggregate (\%) & $14.9 \mathrm{c}$ & $16.95 \mathrm{bc}$ & $14.05 \mathrm{c}$ & $17.75 \mathrm{bc}$ & $\begin{array}{c}21.40 \\
a b\end{array}$ & $24.25 \mathrm{a}$ & $20.15 \mathrm{ab}$ \\
\hline \multicolumn{8}{|c|}{ Soil particle group (\%) } \\
\hline Clay & $7.21 \mathrm{a}$ & $7.74 \mathrm{a}$ & $8.89 \mathrm{a}$ & $7.39 \mathrm{a}$ & $7.73 \mathrm{a}$ & $7.71 \mathrm{a}$ & $8.03 \mathrm{a}$ \\
\hline Silt & $60.14 \mathrm{e}$ & $60.77 \mathrm{de}$ & $\begin{array}{c}63.69 \\
\text { bcd }\end{array}$ & $62.79 \mathrm{cde}$ & $\begin{array}{c}66.54 \\
a b\end{array}$ & $68.1 \mathrm{a}$ & $65.68 \mathrm{abc}$ \\
\hline Sand & $32.65 \mathrm{a}$ & $31.49 \mathrm{a}$ & $\begin{array}{c}27.42 \\
\text { bcd }\end{array}$ & $29.82 \mathrm{ab}$ & $\begin{array}{c}25.73 \\
\mathrm{~cd}\end{array}$ & $24.19 \mathrm{~d}$ & $26.29 \mathrm{~cd}$ \\
\hline
\end{tabular}

Numbers followed by different small letters in the same row are significant at $P<0.05$.

The trend line in Fig. 1 shows that the increasing rate of SOC with fertilizer treatments (except for N1P0 treatment) was from $0.042 \mathrm{~g} \mathrm{~kg}^{-1} \mathrm{y}^{-1}$ (N2P0) to $0.089 \mathrm{~g} \mathrm{~kg}^{-1} \mathrm{y}^{-1}$ (N2P1), ranked as $\mathrm{N} 2 \mathrm{P} 1>\mathrm{N} 1 \mathrm{P} 2>\mathrm{N} 1 \mathrm{P} 1>\mathrm{N} 2 \mathrm{P} 2>\mathrm{N} 2 \mathrm{P} 0>\mathrm{N} 0 \mathrm{P} 0$. Among the treatments, N1P2 attained the largest increases in both SOC content (22.7\%) and millet yield (280.9\%). After N1P2, millet yield declined in the sequence $\mathrm{N} 2 \mathrm{P} 2>\mathrm{N} 2 \mathrm{P} 1>\mathrm{N} 1 \mathrm{P} 1>\mathrm{N} 2 \mathrm{P} 0>\mathrm{N} 1 \mathrm{P} 0>\mathrm{N} 0 \mathrm{P} 0$ (Fig. 3).

Although millet yield increased with increasing fertilizer of $\mathrm{N}$ and P, SOC did not show the same trend as yield. Although several treatments received a larger total amount of fertilizer than N1P2, SOC decreased by $7.4 \%$ (N2P0), 3.4\% (N2P1), and 15.7\% (N2P2) in response to extra nutrient additions compared with N1P2. When N was added without $\mathrm{P}$ (N1P0 and N2P0), the change through time of SOC content and millet yield was similar to plots receiving no fertilizer (NOP0), implying a limitation of soil available $\mathrm{P}$ on millet growth and SOC storage in this situation. The combined fertilization of the $\mathrm{N}$ and $\mathrm{P}$ treatments was superior to $\mathrm{N}$ addition alone in enhancing both SOC content and millet yield.

Generally, enhanced input of $\mathrm{N}$ and $\mathrm{P}$ fertilizer to soil will increase crop yield, amount of residue returned, and SOC. However, this is not always the case. It depends on the nutrient content, nutrient balance, nutrient requirements of the specific crop, soil water status, and other factors [40-42]. In this research, millet yield increased with the enhanced fertilizer input from N1P0 to N2P0, N1P1 and N1P2, but the yield did not increase continuously when $\mathrm{N}$ and $\mathrm{P}$ input are enhanced further at $\mathrm{N} 2 \mathrm{P} 1$ and N2P2 treatments. This could be attributed to the input of N and P in N1P2 treatment meeting the maximum nutrient requirement under the specific soil water regime and climate of the study region. A higher addition rate of $\mathrm{P}$ than $\mathrm{N}$ appears superior for millet yield, likely because the local soil in the hilly Loess Plateau is calcareous and extremely limited by available P (mean available P in P0,

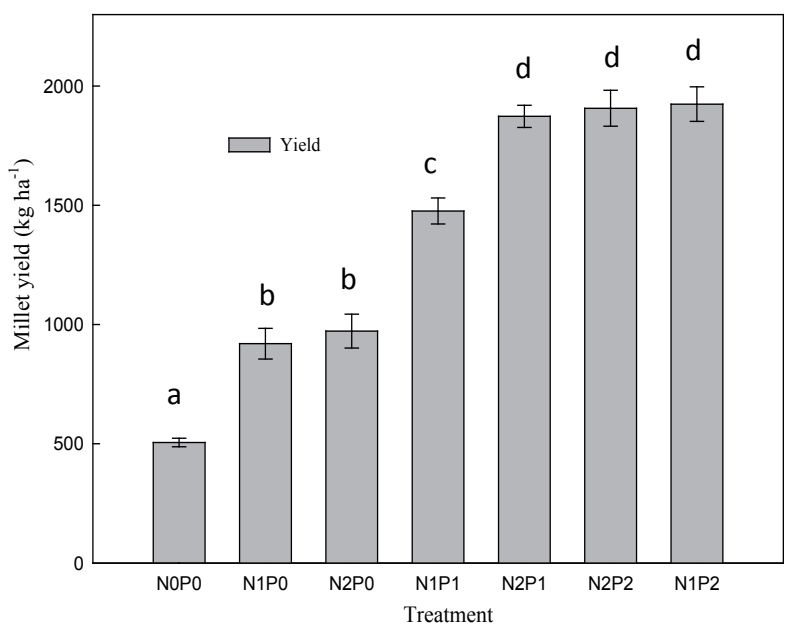

Fig. 3. Millet yield in the different treatments. Different letters indicate significant differences at the 0.05 level. 
$\mathrm{P} 1$ and $\mathrm{P} 2$ treatments were $1.65 \mathrm{mg} \mathrm{kg}^{-1}, 9.96 \mathrm{mg} \mathrm{kg}^{-1}$, and $23.66 \mathrm{mg} \mathrm{kg}^{-1}$, respectively) [31].

With the increased millet yield one could expect an increase of SOC due to increased residue return. However, when the fertilizer additions exceeded those delivered in N1P2, SOC was lower than N1P2, suggesting that additional fertilization reduces $\mathrm{C}$-storage. This could be explained by the interaction of nutrient stoichiometry and microbial activity in the soil system [43-45]. The availability of essential soil nutrients (e.g., $\mathrm{N}$ and $\mathrm{P}$ ) could influence the activities, biomass, and compositions of soil microbial communities [38, 46]. As a result of priming effect, $\mathrm{N}$ and $\mathrm{P}$ addition stimulates microbial activity and speeds up the mineralization of soil organic material (root residue, source of total $\mathrm{N}$ and $\mathrm{P}$ ), as well as the uptake of available $\mathrm{N}$ and $\mathrm{P}$ by both microbes and plant [25, 4748]. When less $\mathrm{N}$ and $\mathrm{P}$ were added to the soil, microbial activity may have been limited by an unsuitable $C: N$ :P ratio (Fig. 4). In this case the mineralization of returned residue would have been suppressed and SOC storage increased (treatments of N1P0, N1P1, and N1P2). Related research in sandy soils under Mediterranean climate showed that there was a significant and positive effect of residue $\mathrm{C}$ input on hay crop $\mathrm{C}$ balance, indicating that more residue- $\mathrm{C}$ was retained in soil rather than mineralized under suppressed microbial activity [49]. With the enhanced input of $\mathrm{N}$ and $\mathrm{P}$, soil microbial activity was stimulated gradually (Fig. 4), possibly accelerating the mineralization of returned residue and decreasing SOC storage (treatments of $\mathrm{N} 2 \mathrm{P} 0, \mathrm{~N} 2 \mathrm{P} 1$, and $\mathrm{N} 2 \mathrm{P} 2$ ). This in turn may have resulted in a decrease of soil $\mathrm{C}$ and Total $\mathrm{N}$ (SOC is the main source of $\mathrm{N}$ ), but increase of available $\mathrm{N}$ and $\mathrm{P}$ (Fig. 5). As a whole, soil $\mathrm{C}$ and $\mathrm{N}$ storage may have been a result of the effect of C:N:P stoichiometry on microbial biomass (Table 3). Microbes may have initially been $\mathrm{N}$-limited, but as $\mathrm{N}$ was added the $\mathrm{C}: \mathrm{N}$ ratio became lower to the point that microbes may have become $\mathrm{C}$-limited and consumed organic soil C. Enhanced fertilization beyond the rates added in N1P2 does not lead to further increase of SOC and total nitrogen.

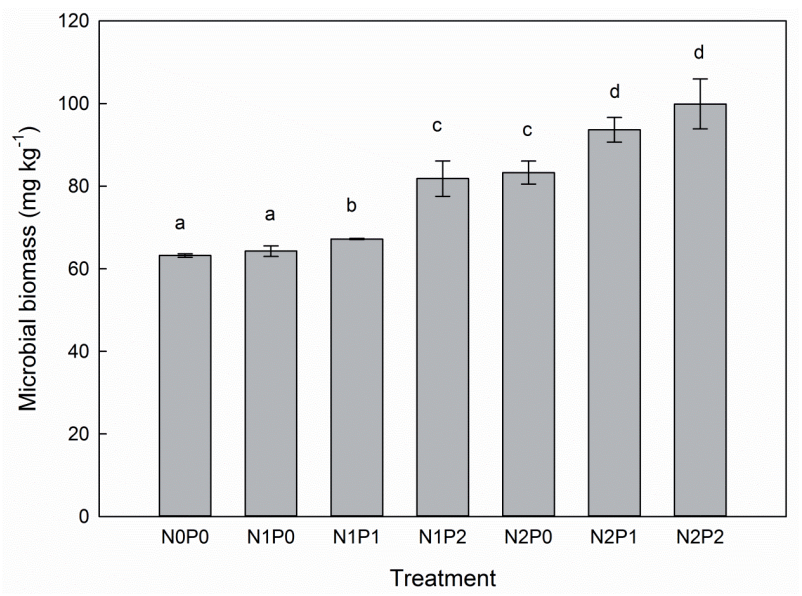

Fig. 4. Soil microbial biomass $\mathrm{C}$ in different fertilization treatments. Different letters indicate significant differences at the 0.05 level.
Based on these results, in addition to maintaining a balance of nutrients, sound management should avoid excessive application of fertilizer to maximize soil fertility improvement and sustainable soil management.

\section{Soil N Fractions and Plant N Uptake in the Different Treatments}

The $\mathrm{N}$ input significantly affected the contents of total $\mathrm{N}$ and available $\mathrm{N}$ content in the soil and plant $\mathrm{N}$ (or C) uptake (Figs 2, 5). The $\mathrm{N}$ export in the form of aboveground plant biomass ranged from $11.9 \mathrm{~kg} \mathrm{ha}^{-1}$ in $\mathrm{N} 1 \mathrm{P} 0$ to $42.0 \mathrm{~kg} \mathrm{ha}^{-1}$ in N1P2, accounting for $21.6 \%$ and $76.1 \%$ of the applied N, respectively (Fig. 5). Compared

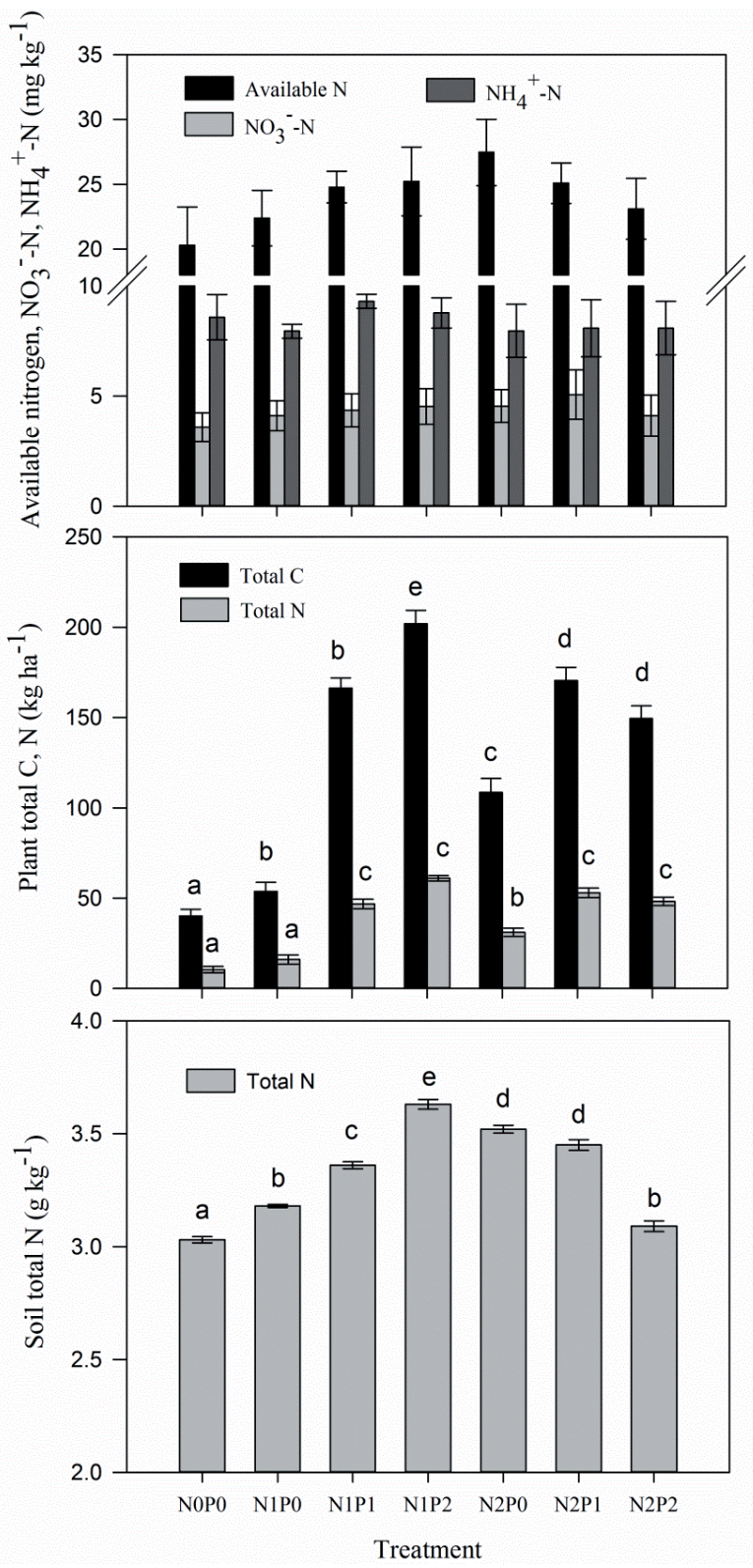

Fig. 5. Soil $\mathrm{N}$ fractions and plant $\mathrm{C}$ and $\mathrm{N}$ uptake of long-term chemical fertilized soil after 17 years. Different letters indicate significant differences between treatments at the 0.05 level. 
Table 3. Correlation between soil C, N, P ration, and biomass C in the slope cropland after 17-year chemical fertilization $(\mathrm{n}=7)$.

\begin{tabular}{|c|c|c|c|c|c|c|}
\hline & Soil C/N & Soil C/P & Soil N/P & Soil AN/AP & Biomass C & Yield \\
\hline Soil C/N & 1 & & & & & \\
\hline Soil C/P & 0.009 & 1 & & & & \\
\hline Soil N/P & -0.326 & $0.942 * *$ & 1 & & & \\
\hline Soil AN/AP & 0.508 & -0.149 & -0.297 & 1 & & 1 \\
\hline Biomass C & $-0.915 * *$ & 0.237 & 0.535 & -0.502 & & \\
\hline Yield & -0.607 & 0.422 & 0.597 & $-0.790 *$ & $0.746^{*}$ & 1 \\
\hline
\end{tabular}

AN and AP denote available nitrogen and available phosphorus, respectively. *, ** Correlation is significant at $P<0.05$ and $P<0.01$, respectively.

with NOP0, average incremental increases in soil total $\mathrm{N}$ of $12.4 \%$ and available $\mathrm{N}$ of $21.5 \%$ were found in the fertilized treatments. For the N-only treatments, we observed a significant increase in the total $\mathrm{N}$ content and non-significant increase in the available $\mathrm{N}$ content as the $\mathrm{N}$ input was enhanced. Overall, the joint $\mathrm{N}$ and $\mathrm{P}$ addition treatments resulted in greater total $\mathrm{N}$ content and available N content compared with $\mathrm{N}$ alone. Similarly to the response of SOC to enhanced input of $\mathrm{N}$ and $\mathrm{P}$, total $\mathrm{N}$ showed a declining trend when fertilizer addition amount increased from N1P2 to N2P0, N2P1, and N2P2, with a decrease by $2.9 \%, 4.9 \%$, and $14.8 \%$, respectively, compared with N1P2.

$\mathrm{NO}_{3}^{-}-\mathrm{N}$ and $\mathrm{NH}_{4}^{+}-\mathrm{N}$ averaged $52.2 \%$ of available $\mathrm{N}$ in the soil and did not differ among treatments. The $\mathrm{NO}_{3}^{-}-\mathrm{N}$ content did not exceed $5.5 \mathrm{mg} \mathrm{kg}^{-1}$, or approximately half the $\mathrm{NH}_{4}^{+}-\mathrm{N}$ content, indicating that $\mathrm{NH}_{4}^{+}-\mathrm{N}$, which generally exists as a positive electrical charge and is easily adsorbed by soil colloids [50], was slowly transformed at a constant rate into $\mathrm{NO}_{3}^{-}-\mathrm{N}$ at the millet maturity stage despite the differences in the application levels of $\mathrm{N}$.

$\mathrm{N}$ fertilizer is of great importance in crop production. In the present study, the levels of chemical fertilization significantly affected $\mathrm{N}$ utilization efficiency and yield sustainability (Table 4). Data from the 17-year experiment showed that the internal $\mathrm{N}$ use efficiency (IE) was the highest in the NOP0 treatment, wherein the entire N came from the soil, causing $\mathrm{N}$ deficit and low SYI (0.550). Compared with NOP0, a significant decline in IE was observed while a significant increase in SYI (except for $\mathrm{N} 1 \mathrm{P} 0$ ) was found in the fertilized treatments.

The addition of combined chemical fertilization led to a significant increase in $\mathrm{N}$ agronomic efficiency (NAE) and $\mathrm{N}$ apparent recovery efficiency (NRE) compared with the $\mathrm{N}$-only treatments. In the present study, however, the levels of chemical fertilization did not significantly affect the NAE and NRE. Among the combined treatments, N1P2 obtained the most preferable IE, NAE, NRE, and SYI, indicating the close relationship between soil sustainability and plant $\mathrm{N}$ uptake and $\mathrm{N}$ utilization efficiency [29]. Although N2P2 obtained the highest SYI, $\mathrm{N} 1 \mathrm{P} 2$ remains the optimal fertilizer treatment in the local region because N2P2 has relatively low NAE and NRE, suggesting that a considerable amount of $\mathrm{N}$ would be lost mainly because of leaching and erosion [16]. Therefore, sustainable soil management in a sloping cropland should not only take into consideration crop production, but $\mathrm{N}$ utilization efficiency as well.

$\mathrm{NO}_{3}^{-}-\mathrm{N}$ and $\mathrm{NH}_{4}^{+}-\mathrm{N}$ are the main forms of $\mathrm{N}$ that agronomic plants consume and represent the capacity of soil N supply [51]. Higher inorganic N content in soil is beneficial to plant $\mathrm{N}$ uptake. Soil inorganic $\mathrm{N}$ fraction management in cropland is a complex process that integrates nitrification, immobilization, volatilization, denitrification, and leaching under aerobic and anaerobic conditions [52]. Thus, results from literature vary according to the soil or cropping systems used. Chandel found that total $\mathrm{N}$ accumulation rates did not match with SOC sequestration rates[15]. Moreover, crop $\mathrm{N}$ removal is well

Table 4. Nitrogen utilization efficiency (NUE) and sustainability in the different treatments.

\begin{tabular}{|c|c|c|c|c|c|c|c|}
\hline $\begin{array}{c}\text { Treatment } \\
\text { Fertilizers }\end{array}$ & N2P2 & N2P1 & N2P0 & N1P2 & N1P1 & N1P0 & N0P0 \\
\hline IE $\left(\mathrm{kg} \mathrm{kg}^{-1}\right)$ & $36.14 \mathrm{~b}$ & $30.77 \mathrm{c}$ & $27.20 \mathrm{~d}$ & $26.83 \mathrm{~d}$ & $35.83 \mathrm{~b}$ & $35.34 \mathrm{~b}$ & $40.04 \mathrm{a}$ \\
\hline NAE $\left(\mathrm{kg} \mathrm{kg}^{-1}\right)$ & $11.99 \mathrm{~b}$ & $10.99 \mathrm{~b}$ & $3.86 \mathrm{c}$ & $22.07 \mathrm{a}$ & $22.78 \mathrm{a}$ & $2.68 \mathrm{c}$ & -- \\
\hline NRE $(\%)$ & $43.67 \mathrm{c}$ & $48.03 \mathrm{c}$ & $28.12 \mathrm{~d}$ & $110.51 \mathrm{a}$ & $84.74 \mathrm{~b}$ & $29.02 \mathrm{~d}$ & -- \\
\hline SYI & $0.770 \mathrm{ab}$ & $0.825 \mathrm{a}$ & $0.672 \mathrm{~b}$ & $0.801 \mathrm{a}$ & $0.778 \mathrm{a}$ & $0.410 \mathrm{~d}$ & $0.550 \mathrm{c}$ \\
\hline
\end{tabular}

IE, NAE, NRE, and SYI denote internal $\mathrm{N}$ use efficiency, $\mathrm{N}$ agronomic efficiency, $\mathrm{N}$ apparent recovery efficiency, and sustainable yield index, respectively. Numbers followed by different small letters in the same row are significant at $P<0.05$. 
Table 5. Correlation between soil inorganic $\mathrm{N}$ fractions, total $\mathrm{C}, \mathrm{N}$ in the shoot, and physical properties in the slope cropland after 17-year chemical fertilization $(\mathrm{n}=21)$.

\begin{tabular}{|c|c|c|c|c|c|c|c|c|c|}
\hline Parameters & $\begin{array}{c}\mathrm{SOC} \\
\left(\mathrm{g} \mathrm{kg}^{-1}\right)\end{array}$ & $\begin{array}{l}\text { Total N } \\
\left(\mathrm{g} \mathrm{kg}^{-1}\right) \\
\end{array}$ & $\begin{array}{l}\text { Soil } \\
\mathrm{C} / \mathrm{N}\end{array}$ & $\begin{array}{c}\text { Available N } \\
\left(\mathrm{mg} \mathrm{kg}^{-1}\right)\end{array}$ & $\begin{array}{l}\mathrm{NO}_{3}{ }^{-}-\mathrm{N} \\
\left(\mathrm{mg} \mathrm{kg}^{-1}\right)\end{array}$ & $\begin{array}{l}\mathrm{NH}_{4}^{+}-\mathrm{N} \\
\left(\mathrm{mg} \mathrm{kg}^{-1}\right)\end{array}$ & $\begin{array}{l}\text { Shoot C } \\
\left(\mathrm{g} \mathrm{kg}^{-1}\right)\end{array}$ & $\begin{array}{c}\text { Shoot N } \\
\left(\mathrm{g} \mathrm{kg}^{-1}\right)\end{array}$ & $\begin{array}{l}\text { Shoot } \\
\text { C/N }\end{array}$ \\
\hline $\begin{array}{l}\text { Bulk density } \\
\qquad\left(\mathrm{g} \mathrm{cm}^{-3}\right)\end{array}$ & -0.193 & -0.040 & -0.387 & -0.168 & 0.204 & -0.118 & -0.236 & -0.269 & $-0.630^{*}$ \\
\hline $\begin{array}{l}\text { Porosity } \\
\left(\%, \mathrm{v} \mathrm{v}^{-1}\right)\end{array}$ & 0.024 & 0.121 & 0.366 & 0.051 & -0.092 & 0.072 & 0.157 & 0.202 & $0.623 *$ \\
\hline \multicolumn{10}{|c|}{ Aggregate size distribution (\%) } \\
\hline$>5 \mathrm{~mm}$ & $0.680 *$ & $0.563 *$ & -0.120 & 0.430 & 0.345 & 0.068 & 0.531 & $0.598 *$ & $-0.616 *$ \\
\hline $5-2 \mathrm{~mm}$ & $\begin{array}{c}0.913 \\
* *\end{array}$ & $0.562 *$ & 0.059 & 0.546 & 0.133 & 0.034 & 0.526 & $0.593 *$ & -0.426 \\
\hline $2-1 \mathrm{~mm}$ & $0.637 *$ & $0.653 *$ & 0.006 & $0.686 *$ & 0.566 & -0.022 & 0.552 & $0.591 *$ & -0.119 \\
\hline $1-0.5 \mathrm{~mm}$ & $0.778 *$ & 0.382 & -0.216 & $0.655 *$ & 0.330 & 0.031 & 0.522 & 0.403 & -0.483 \\
\hline $0.5-0.25 \mathrm{~mm}$ & 0.378 & 0.267 & -0.209 & $0.613 *$ & 0.262 & 0.162 & 0.452 & 0.462 & $-0.604 *$ \\
\hline \multicolumn{10}{|c|}{ Soil particle group (\%) } \\
\hline Sand & -0.453 & $-0.650 *$ & 0.390 & $-0.735 *$ & $-0.703 *$ & -0.070 & $-0.681 *$ & $-0.716 *$ & $0.690 *$ \\
\hline Silt & $0.573^{*}$ & $0.574 *$ & -0.369 & 0.389 & 0.283 & 0.154 & $0.610 *$ & $0.643 *$ & $-0.600 *$ \\
\hline Clay & $0.595 *$ & $0.637 *$ & -0.242 & $0.709 *$ & $0.694 *$ & 0.432 & $0.616 *$ & $0.645 *$ & $-0.622 *$ \\
\hline
\end{tabular}

SOC denotes soil organic carbon. * ** Correlation is significant at $P<0.05$ and $P<0.01$, respectively.

correlated with fertilizer $\mathrm{N}$ inputs ( $\mathrm{p}<0.01$ ), and $\mathrm{N}$ removed by rice and straw even accounted for $37 \%$ to $39 \%$ of the applied $\mathrm{N}$ annually. The combined $\mathrm{N}$ and $\mathrm{P}$ fertilization tends to result in significantly higher concentrations of mineral $\mathrm{N}$ compared with either $\mathrm{N}$ or $\mathrm{P}$ added alone [13]. However, high $\mathrm{N}$ application does not assure higher fruit and/or shoot biomass or $\mathrm{N}$ accumulation benefits. On the contrary, high $\mathrm{N}$ application substantially increases $\mathrm{NO}_{3}^{-}-\mathrm{N}$ leaching [53]. Thus, a judicious rate of $\mathrm{N}$ application should be determined through a plant life cycle analysis in the long-term. Our results could provide a reference for rational $\mathrm{N}$ application on cropland in similar regions.

\section{Soil Physical Properties and Their Relationships with Soil N Fractions, Plant C Content, and $\mathrm{N}$ Uptake}

Soil bulk density did not differ among treatments (Table 2). Compared with NOP0, fertilized treatments experienced a decrease in the proportion of smaller aggregates $(<2 \mathrm{~mm})$ relative to a proportional increase in large aggregates $(>2 \mathrm{~mm})$. This result was congruent with increases of SOC, which indicates enhanced growth of roots that contribute to the creation of large aggregates. The increase in aggregate size was most notable in N1P2 and N2P1. In fertilized plots, the clay and silt content increased by $2.5-23.3 \%$ (average 9.8\%) and 1.0-13.2\% (average $7.4 \%$ ), respectively, while the sand contents decreased by 3.6-25.9\% (average 15.8\%) compared with those in N0P0. Furthermore, the combined treatments gained the highest increment in silt content and decrement in sand content.

The relationships among soil $\mathrm{N}$ fractions, shoot $\mathrm{C}$, shoot N, and physical properties of soil samples collected during the millet harvest stage after 17 years are shown in Table 5. Soil bulk density showed a strongly negative correlation with shoot $\mathrm{C}: \mathrm{N}$ ratio, while it was not clearly correlated to $\mathrm{SOC}$, total $\mathrm{N}$, and the other variables. The SOC, total soil $\mathrm{N}$ content, shoot $\mathrm{C}$, and shoot $\mathrm{N}$ demonstrated close positive relationships with the relative large aggregate abundances and the clay content. Among the soil inorganic $\mathrm{N}$ fractions, the available $\mathrm{N}$ showed significant correlation with the smaller aggregates and clay content, while the $\mathrm{NO}_{3}{ }^{-}-\mathrm{N}$ and $\mathrm{NH}_{4}^{+}-\mathrm{N}$ concentrations exhibited irregular changes except for a positive relationship with clay content.

Soil physical processes are extremely important in cultivated soils. In the hilly Loess Plateau chemical fertilizers are the only choice in most cases because of the lack of organic manure. Land managers fear that the longterm application of chemical fertilizers to the soils on slope land susceptible to erosion could lead to a degradation of soil physical quality. Our results demonstrated that no obvious degradation of soil physical properties was found after long-term chemical fertilization in the slope cropland. On the contrary, the amount and stability of soil aggregates were increased significantly in the treatments of combined $\mathrm{N}$ and $\mathrm{P}$ fertilizer compared with no chemical fertilizer application after a 17 -year cropping period. SOC is considered as a binding agent and a nucleus in the formation of soil aggregates [5]. The improvement of soil 
structure could be contributed to the increase of SOC in the related fertilizer treatments. Similar research reported that balanced mineral fertilization in a rice-wheat rotation in sandy loam and in a wheat-maize rotation improved the mean weight diameter of aggregates since the application of balanced mineral fertilizer can improve the growth of crops and increase organic matter return to the soil [54-55]. The increase in the proportion of large aggregates $(>5 \mathrm{~mm})$ with long-term $\mathrm{N}$ and $\mathrm{P}$ combined fertilization (except N2P2) reflected an obvious improvement of soil structure condition in the inorganic fertilization cropping system. The close relationship between soil $\mathrm{N}$ and soil aggregation was reasonable in light of the fact that SOC and soil $\mathrm{N}$ contents were increased after long-term chemical fertilization. SOC is closely related with aggregate formation and stability. In this way SOC links responses of the soil $\mathrm{N}$ and soil aggregation together [5, 56-57].

Benefit from the improvement of soil aggregated structure and soil erodibility could be enhanced accordingly, and erosion-induced soli particle (clay, silt, and sand) separation process was changed, which causes an indirect impact on soil texture with more clay and silt retained in the soil [7-9]. In fertilized sloping plots in our experiment, the clay and silt content increased by $9.8 \%$ and $7.4 \%$, respectively, while the sand contents decreased by $15.8 \%$ compared with no chemical fertilizer treatment plots. The $\mathrm{N}$ and $\mathrm{P}$ combined treatments gained the highest increment in silt content and decrement in sand content. The changes in soil particles demonstrated that soil texture was improved after long-term chemical fertilization on sloping cropland. Given the positive effects of long-term chemical fertilizer application on crop production, soil organic matter content, soil aggregate stability, and soil texture, balanced $\mathrm{C}$ and $\mathrm{N}$ application provides a means to add SOC, which in turn creates positive physical soil properties to the infertile loess soil for improvement and sustainability of the slope-cropping system on the hilly Loess Plateau.

Mountainous regions cover $22 \%$ of the earth's land area and are home to $13 \%$ of the world's population. The number of people vulnerable to food insecurity in such regions has risen at a higher rate than population growth in the same regions [1]. It will be a major challenge to meet the food demand for the growing world population, given that sloping cropland is prone to erosion, drought, infertility, and desertification, especially in semi-arid regions. We can expect that inorganic fertilizer application on sloping cropland will become more prevalent in an effort to combat poverty and food shortages in mountainous regions in the future as populations continue to grow. Our research results indicate that, at least in the case of the Loess Plateau, long-term chemical fertilization of sloping cropland enhances yield and fertility without compromising soil structure. This will provide scientific support for rational and balanced fertilizer applications for a sustainable agricultural system in the mountainous regions of the world.

\section{Conclusions}

Long-term balanced chemical fertilization can sustain the soil quality of an infertile slope cropland on the hilly Loess Plateau. After 17 years of continuous chemical fertilizer application SOC and soil total $\mathrm{N}$ content increased by $12.9 \%$ and $12.4 \%$ on average as compared with plots receiving no fertilizer application. Despite the fear that long-term application of chemical fertilizers to the slope cropland could lead to soil physical degradation, no obvious degradation of soil physical properties was found after 17 years of chemical fertilization in the slope land. On the contrary, improvement of soil structure was attained due to a proportional increase of large aggregates relative to small aggregates, as well as an increase in the total amount of water stable aggregates. This increase of SOC and soil total $\mathrm{N}$ and the improvement of soil structure were attributed to better availability of soil inorganic $\mathrm{N}$ fractions.

However, excessive fertilization could stimulate soil microbial activity in unfavorable ways, accelerating mineralization of organic material and causing declines in SOC and soil total nitrogen. A rational fertilization strategy should take into account both the amount of nutrients added and the balance of different nutrients to improve soil fertility and promote sustainable soil management. In contrast, treatments which added $\mathrm{N}$ alone or added no nutrients obtained relatively low IE, NAE, NRE, and SYI, while balanced fertilization of $\mathrm{N}$ and $\mathrm{P}$ were superior in enhancing SOC, total and available $\mathrm{N}$ content, and millet yield. Comparatively, N1P2 was the optimal fertilizer treatment in the eroded slope cropland on the hilly Loess Plateau.

\section{Acknowledgements}

This research was financially supported by the Special Program for Basic Research of the Ministry of Science and Technology, China (2014FY210100), the Key Research Program of the Chinese Academy of Sciences (KJZD-EW-TZ-G10), and the National Natural Science Foundation of China (41171422). We express our gratitude to Dr. Nancy Johnson, professor at Northern Arizona University, and the anonymous reviewers and editors for their constructive comments and suggestions.

\section{References}

1. FAO. Food and agriculture, key to achieving the 2030 agenda for sustainable development. Rome, FAO; 2016.

2. XIN X., ZHANG J., ZHU A., ZHANG C. Effects of longterm (23 years) mineral fertilizer and compost application on physical properties of fluvo-aquic soil in the North China Plain. Soil and Tillage Research. 156, 166, 2016.

3. NORMAN C.R., BRYE K.R., GBUR E.E., CHEN P., RUPE J. Long-term Management Effects on Soil Properties and 
Yields in a Wheat-Soybean Double-Crop System in Eastern Arkansas. Soil Science. 181 (1), 1, 2016.

4. NIU L.A., HAO J.M., ZHANG B.Z., NIU X. Influences of long-term fertilizer and tillage management on soil fertility of the North China Plain. Pedosphere. 21 (6), 813, 2011.

5. BRONICK C.J., LAL R. Soil structure and management: a review. Geoderma. 124 (1), 3, 2005.

6. HAYNES R., NAIDU R. Influence of lime, fertilizer and manure applications on soil organic matter content and soil physical conditions: a review. Nutrient cycling in agroecosystems. 51 (2), 123, 1998.

7. YAN Y., XIN X., XU X., WANG X., YANG G., YAN R., CHEN B. Quantitative effects of wind erosion on the soil texture and soil nutrients under different vegetation coverage in a semiarid steppe of northern China. Plant and soil. 369 (1-2), 585, 2013.

8. CIARKOWSKA K. Effect of fertilization on the structure of upland grassland soil. Pol J Environ Stud. 19 (4), 693, 2010.

9. XU M., LI Q., WILSON G. Degradation of soil physicochemical quality by ephemeral gully erosion on sloping cropland of the hilly Loess Plateau, China. Soil and Tillage Research. 155, 9, 2016.

10. SAINJU U.M., WHITEHEAD W.F., SINGH B.P., WANG S. Tillage, cover crops, and nitrogen fertilization effects on soil nitrogen and cotton and sorghum yields. European Journal of Agronomy. 25 (4), 372, 2006.

11. LIU E., YAN C., MEI X., ZHANG Y., FAN T. Long-term effect of manure and fertilizer on soil organic carbon pools in dryland farming in northwest China. Plos one. 8 (2), e56536, 2013.

12. SINGH BRAR B., SINGH J., SINGH G., KAUR G. Effects of long term application of inorganic and organic fertilizers on soil organic carbon and physical properties in maizewheat rotation. Agronomy. 5 (2), 220, 2015.

13. SHISANYA C.A., MUCHERU M.W., MUGENDI D.N., KUNG'U J.B. Effect of organic and inorganic nutrient sources on soil mineral nitrogen and maize yields in central highlands of Kenya. Soil and Tillage Research. 103 (2), 239, 2009.

14. PELSTER D.E., LAROUCHE F., ROCHETTE P., CHANTIGNY M.H., ALLAIRE S., ANGERS D.A. Nitrogen fertilization but not soil tillage affects nitrous oxide emissions from a clay loam soil under a maize-soybean rotation. Soil and Tillage Research. 115, 16, 2011.

15. CHANDEL G., BANERJEE S., SEE S., MEENA R., SHARMA D., VERULKAR S. Effects of different nitrogen fertilizer levels and native soil properties on rice grain $\mathrm{Fe}, \mathrm{Zn}$ and protein contents. Rice Science. 17 (3), 213, 2010.

16. SHI Z., LI D., JING Q., CAI J., JIANG D., CAO W., DAI T. Effects of nitrogen applications on soil nitrogen balance and nitrogen utilization of winter wheat in a rice-wheat rotation. Field Crops Research. 127 (2) 41, 2012.

17. CHAUDHARY S., DHERI G., BRAR B. Long-term effects of NPK fertilizers and organic manures on carbon stabilization and management index under rice-wheat cropping system. Soil and Tillage Research. 166, 59, 2017.

18. VAN EERD L.L., CONGREVES K.A., HAYES A., VERHALLEN A., HOOKER D.C. Long-term tillage and crop rotation effects on soil quality, organic carbon, and total nitrogen. Canadian Journal of Soil Science. 94 (3), 303, 2014

19. SRINIVASARAO C., VENKATESWARLU B., LAL R., SINGH A., KUNDU S., VITTAL K., PATEL J., PATEL $\mathrm{M}$. Long- term manuring and fertilizer effects on depletion of soil organic carbon stocks under pearl millet- cluster bean- castor rotation in western india. Land Degradation \& Development. 25 (2), 173, 2014.

20. LEE S.B., LEE C.H., JUNG K.Y., DO PARK K., LEE D., KIM P.J. Changes of soil organic carbon and its fractions in relation to soil physical properties in a long-term fertilized paddy. Soil and Tillage Research. 104 (2), 227, 2009.

21. RABBI S.F., WILSON B.R., LOCKWOOD P.V., DANIEL H., YOUNG I.M. Soil organic carbon mineralization rates in aggregates under contrasting land uses. Geoderma. 21610, 2014.

22. JUNG J.Y., LAL R. Impacts of nitrogen fertilization on biomass production of switchgrass (Panicum virgatum L.) and changes in soil organic carbon in Ohio. Geoderma. 166 (1), 145, 2011.

23. CAI A., XU H., SHAO X., ZHU P., ZHANG W., XU M., MURPHY D.V. Carbon and Nitrogen Mineralization in Relation to Soil Particle-Size Fractions after 32 Years of Chemical and Manure Application in a Continuous Maize Cropping System. PloS one. 11 (3), e 0152521, 2016.

24. FAGERIA N., BALIGAR V. Enhancing nitrogen use efficiency in crop plants. Advances in agronomy. 8897, 2005.

25. RAMIREZ K.S., CRAINE J.M., FIERER N. Nitrogen fertilization inhibits soil microbial respiration regardless of the form of nitrogen applied. Soil Biology and Biochemistry. 42 (12), 2336, 2010.

26. CHEN H., ZHAO Y., FENG H., LI H., SUN B. Assessment of climate change impacts on soil organic carbon and crop yield based on long-term fertilization applications in Loess Plateau, China. Plant and Soil. 390 (1-2), 401, 2015.

27. YANG X., LI P., ZHANG S., SUN B., XINPING C. Longterm- fertilization effects on soil organic carbon, physical properties, and wheat yield of a loess soil. Journal of Plant Nutrition and Soil Science. 174 (5), 775, 2011.

28. ZHOU D., ZHAO S., ZHU C. The Grain for Green Project induced land cover change in the Loess Plateau: a case study with Ansai County, Shanxi Province, China. Ecological indicators. 23, 88, 2012.

29. YAN X., GONG W. The role of chemical and organic fertilizers on yield, yield variability and carbon sequestrationresults of a 19-year experiment. Plant and soil. 331 (1-2), 471, 2010.

30. STAFF S.S. Soil taxonomy. USDA-NRCS, US Gov. Print. Office Washington, DC; 1999.

31. XU M., ZHAO Y., LIU G., WILSON G. Identification of soil quality factors and indicators for the Loess Plateau of China. Soil Science. 171 (5), 400, 2006.

32. NELSON D., SOMMERS L.E. Total carbon, organic carbon, and organic matter. Methods of soil analysis Part 2 Chemical and microbiological properties. (methodsofsoilan2), 539, 1982.

33. NELSON D.W., SOMMERS L.E., SPARKS D., PAGE A., HELMKE P., LOEPPERT R., SOLTANPOUR P., TABATABAI M., JOHNSTON C., SUMNER M. Total carbon, organic carbon, and organic matter. Methods of soil analysis Part 3-chemical methods. 961, 1996.

34. VANCE E., BROOKES P., JENKINSON D. An extraction method for measuring soil microbial biomass C. Soil biology and Biochemistry. 19 (6), 703, 1987.

35. WITT C., DOBERMANN A., ABDULRACHMAN S., GINES H., GUANGHUO W., NAGARAJAN R., SATAWATANANONT S., SON T.T., TAN P.S., SIMBAHAN $\mathrm{G}$. Internal nutrient efficiencies of irrigated lowland rice in tropical and subtropical Asia. Field Crops Research. 63 (2), 113, 1999.

36. CAI Z., QIN S. Dynamics of crop yields and soil organic carbon in a long-term fertilization experiment in the 
Huang-Huai-Hai Plain of China. Geoderma. 136 (3), 708, 2006.

37. SCHJ NNING P., CHRISTENSEN B.T., CARSTENSEN B. Physical and chemical properties of a sandy loam receiving animal manure, mineral fertilizer or no fertilizer for 90 years. European Journal of Soil Science. 45 (3), 257, 1994.

38. LIU E., YAN C., MEI X., HE W., BING S.H., DING L., LIU Q., LIU S., FAN T. Long-term effect of chemical fertilizer, straw, and manure on soil chemical and biological properties in northwest China. Geoderma. 158 (3), 173, 2010.

39. ZHAO H., LIU G., WU R. Nutrient cycling and balance characteristics of different farmland types in the loess hilly region. Trans Chin Soc Agric Eng. 1, 58, 2006.

40. CIAMPITTI I.A., VYN T.J. Nutrient sufficiency concepts for modern corn hybrids: Impacts of management practices and yield levels. Crops and Soils. 47 (4), 38, 2014.

41. SONG C., WANG E., HAN X., STIRZAKER R. Crop production, soil carbon and nutrient balances as affected by fertilisation in a Mollisol agroecosystem. Nutrient Cycling in Agroecosystems. 89 (3), 363, 2011

42. SINGH A.K., BHATT B., SUNDRAM P., KUMAR S., BAHRATI R., CHANDRA N., RAI M. Study of site specific nutrients management of cowpea seed production and their effect on soil nutrient status. Journal of Agricultural Science. 4 (10), 191, 2012.

43. KAISER C., FRANKLIN O., DIECKMANN U., RICHTER A. Microbial community dynamics alleviate stoichiometric constraints during litter decay. Ecology letters. 17 (6), 680, 2014.

44. ZECHMEISTER-BOLTENSTERN S., KEIBLINGER K.M., MOOSHAMMER M., PE UELAS J., RICHTER A., SARDANS J., WANEK W. The application of ecological stoichiometry to plant-microbial-soil organic matter transformations. Ecological Monographs. 85 (2), 133, 2015.

45. SINSABAUGH R.L., MANZONI S., MOORHEAD D.L., RICHTER A. Carbon use efficiency of microbial communities: stoichiometry, methodology and modelling. Ecology letters. 16 (7), 930, 2013.

46. MBUTHIA L.W., ACOSTA-MARTINEZ V., DEBRYUN J., SCHAEFFER S., TYLER D., ODOI E., MPHESHEA M., WALKER F., EASH N. Long term tillage, cover crop, and fertilization effects on microbial community structure, activity: Implications for soil quality. Soil Biology and Biochemistry. 89, 24, 2015.

47. WANG J., XIONG Z., KUZYAKOV Y. Biochar stability in soil: meta-analysis of decomposition and priming effects. GCB Bioenergy. 8 (3), 512, 2016.
48. JANSSEN B.H. Simple models and concepts as tools for the study of sustained soil productivity in long-term experiments. II. Crop nutrient equivalents, balanced supplies of available nutrients, and NPK triangles. Plant and soil. 339 (1-2), 17, 2011.

49. LAI R., ARCA P., LAGOMARSINO A., CAPPAI C., SEDDAIU G., DEMURTAS C.E., ROGGERO P.P. Manure fertilization increases soil respiration and creates a negative carbon budget in a Mediterranean maize (Zea mays L.)based cropping system. CATENA. 151, 202, 2017.

50. RICHTER J., ROELCKE M. The N-cycle as determined by intensive agriculture-examples from central Europe and China. Nutrient Cycling in Agroecosystems. 57 (1), 33, 2000.

51. LI Z., LIU M., WU X., HAN F., ZHANG T. Effects of longterm chemical fertilization and organic amendments on dynamics of soil organic $\mathrm{C}$ and total $\mathrm{N}$ in paddy soil derived from barren land in subtropical China. Soil and Tillage Research. 106 (2), 268, 2010.

52. SCHLECHT E., BUERKERT A., TIELKES E., BATIONO A. A critical analysis of challenges and opportunities for soil fertility restoration in Sudano-Sahelian West Africa. Nutrient Cycling in Agroecosystems. 76 (2-3), 109, 2006.

53. ZOTARELLI L., DUKES M.D., SCHOLBERG J., MUNOZCARPENA R., ICERMAN J. Tomato nitrogen accumulation and fertilizer use efficiency on a sandy soil, as affected by nitrogen rate and irrigation scheduling. Agricultural Water Management. 96 (8), 1247, 2009.

54. RASOOL R., KUKAL S., HIRA G. Soil physical fertility and crop performance as affected by long term application of FYM and inorganic fertilizers in rice-wheat system. Soil and Tillage research. 96 (1), 64, 2007.

55. RASOOL R., KUKAL S., HIRA G. Soil organic carbon and physical properties as affected by long-term application of FYM and inorganic fertilizers in maize-wheat system. Soil and Tillage Research. 101 (1), 31, 2008.

56. VERHULST N., GOVAERTS B., VERACHTERT E., CASTELLANOS-NAVARRETE A., MEZZALAMA M., WALL P., CHOCOBAR A., DECKERS J., SAYRE K. Conservation agriculture, improving soil quality for sustainable production systems. Advances in soil science: food security and soil quality CRC Press, Boca Raton. 137, 2010.

57. GELAW A.M., SINGH B., LAL R. Organic carbon and nitrogen associated with soil aggregates and particle sizes under different land uses in Tigray, Northern Ethiopia. Land Degradation \& Development. 26 (7), 690, 2015. 